Covert Capital 
The publisher gratefully acknowledges the generous support of the Fletcher Jones Foundation Humanities Endowment Fund of the University of California Press Foundation, which was established by a major gift from the Fletcher Jones Foundation. 


\title{
Covert Capital
}

LANDSCAPES OF DENIAL AND THE MAKING OF U.S. EMPIRE IN THE SUBURBS OF NORTHERN VIRGINIA

\author{
Andrew Friedman
}

\section{甲}

U N I VERSITY OF CALIFORNIA PRESS

BERKELEY LOS ANGELES LONDON 
University of California Press, one of the most distinguished university presses in the United States, enriches lives around the world by advancing scholarship in the humanities, social sciences, and natural sciences. Its activities are supported by the UC Press Foundation and by philanthropic contributions from individuals and institutions. For more information, visit http://www.ucpress.edu.

University of California Press

Berkeley and Los Angeles, California

University of California Press, Ltd.

London, England

(C) 2013 by The Regents of the University of California

Library of Congress Cataloging-in-Publication Data

Friedman, Andrew, 1974-

Covert capital : landscapes of denial and the making of U.S. empire in the suburbs of Northern Virginia / Andrew Friedman.

pages $\mathrm{cm}$. - (American crossroads ; 37)

Includes bibliographical references and index.

ISBN 978-0-520-27464-8 (cloth : alk. paper) — ISBN 978-0-520-27465-5 (pbk. : alk. paper)

I. Intelligence service-United States-History. 2. Federal areas within states-Virginia. 3. Virginia, Northern-Buildings, structures, etc. I. Title.

$$
\begin{aligned}
& \mathrm{JK} 468.16 \mathrm{~F} 76 \quad 2013 \\
& 327.1273009755^{2} 29-\mathrm{dc} 23
\end{aligned}
$$

2013015305

Manufactured in the United States of America
$\begin{array}{llllllllll}22 & 21 & 20 & \text { I9 } & \text { I8 } & \text { I7 } & \text { I6 } & \text { I5 } & \text { I4 } & \text { I3 }\end{array}$
IO $\quad 9 \begin{array}{lllllllll} & 8 & 7 & 6 & 5 & 4 & 3 & 2 & \text { I }\end{array}$

In keeping with a commitment to support environmentally responsible and sustainable printing practices, UC Press has printed this book on Rolland Enviroıoo, a I0०\% post-consumer fiber paper that is FSC certified, deinked, processed chlorine-free, and manufactured with renewable biogas energy. It is acid-free and EcoLogo certified. 
For Asali 
AMERICAN CROSSROADS

Edited by Earl Lewis, George Lipsitz, George Sánchez, Dana Takagi, Laura Briggs, and Nikhil Pal Singh 